\title{
Pop-Up Book of Profession as a Career Service Media for Elementary School Students
}

\author{
Ricco Rivaldi Hasti ${ }^{1}$, Khairul Bariyyah ${ }^{2 *}$, Romia Hari Susanti ${ }^{3}$ \\ 1,2,3 Department of Guidance and Counseling, Universitas Kajuruhan Malang, Malang, Indonesia \\ *Email: khairulbariyyah@unikama.ac.id
}

DOI : $\underline{10.33086 / \text { cej.v3i1.1986 }}$

Submission: March 4, 2021

Revised: April 5, 2021

Accepted: May 3, 2021

\section{Keywords:}

Pop-Up Book, Media, and Career Information Services

\begin{abstract}
Career awareness is part of the career maturity that a child needs to achieve and needs to be provided at the primary school level. One of the media used by counselors/teachers in delivering career counseling services for elementary school children is Pop-up Book. This research is a type of development research that uses the Research and Development (R\&D) technique developed by Borg and Gall until the revision stage of the test results of prospective product users. The research sample was selected using the simple random sampling technique. The research subjects were elementary school students in grade 6 . The researcher involved three experts validates to assess the level, relevance, accuracy, readability, and feasibility of the media (material experts, media experts, and elementary school education experts). The instruments used were an assessment scale and a readability questionnaire for trials on elementary students. The data obtained were quantitative and qualitative data and were analyzed by manual counting using formulas. The professional pop-up book as a medium for primary school student career services developed by researchers has fulfilled relevance, accuracy, readability, and feasibility. These media are declared valid and can be used as alternative media to provide career information services for elementary school students. The results of expert testing and testing of prospective product users obtained 80.2 results with very feasible criteria to be applied and used as an alternative media for guidance and counseling services.
\end{abstract}


Ricco Rivaldi Hasti, et al.

Pop-Up Book of Profession as a Career Service Media for Elementary School Students

Kata Kunci:

Pop-Up Book, Media, Layanan Informasi Karir

\begin{abstract}
Abstrak
Kesadaran karir merupakan bagian dari kematangan karir yang perlu dicapai seorang anak dan perlu diberikan pada tingkat sekolah dasar. Salah satu media yang dapat digunakan konselor/guru dalam penyampaiakan layanan bimbingan konseling karir untuk anak sekolah dasar adalah Pop-up Book. Penelitian ini merupakan jenis penelitian pengembangan yang menggunakan teknik Research and Develompent (R\&D) yang dikembangkan oleh Borg and Gall, sampai tahap revisi hasil uji calon pengguna produk. Sampel penelitian dipilih dengan menggunakan teknik Simple Random Sampling. Subjek penelitian adalah siswa sekolah dasar kelas 6. Untuk menilai tingkat, relevansi, keakuratan, keterbacaan serta kelayakan media peneliti melibatkan 3 validator ahli (ahli materi, ahli media dan ahli ilmu pendidikan sekolah dasar). Instrumen yang digunakan adalah skala penilaian dan angket keterbacaan untuk uji coba pada siswa SD. Data yang diperoleh adalah data kuantitatif berupa hasil penilaian pada format penilaian, data kualitatif berupa hasil saran atau kritik dari para ahli dan calon pengguna produk didalam lembar saran, dan dianalisis dengan cara hitung manual dengan menggunakan rumus, untuk mengetahui jumlah rata-rata penilaian dari ahli. Pop-up book profesi sebagai media layanan karir siswa Sekolah Dasar yang dikembangkan oleh peneliti telah memenuhi penilaian pada kriteria relevansi, keakuratan, keterbacaan serta kelayakan. Media ini dinyatakn valid, dan dapat digunakan sebagai alternatif media dalam proses pemberian layanan informasi karir untuk siswa sekolah dasar. Hasil dari uji ahli dan uji coba calon pengguna produk memperoleh hasil 80,2 dengan kriteria sangat layak untuk diterapkan dan digunakan sebagai alternatif media layanan bimbingan dan konseling.
\end{abstract}

\section{A. Introduction}

The ability to realize responsibilities and career recognition must be instilled as early as possible, mainly since children receive education at primary school levels (Yasmin et al., 2020). When they enter elementary school, the average age of Indonesian children is six years old and finishes at the age of 12 (Istiqomah \& Suyadi, 2019). At the age of 6-12 years, children have different characteristics (Susanto, 2016), they need to understand themselves (Kurniasih, et al., 2020). At this age, children prefer to play, move, enjoy working in groups, and enjoy experiencing or doing new things directly. At this age, children need to be given career guidance considering the career growth stages of a child starting from birth to age 14 (Eliason et al., 2019). Therefore, children need to be prepared and helped to plan their careers. This preparation can be done by providing education and career guidance in primary schools.

Primary schools in Indonesia still rarely have Guidance and Counseling. Therefore providing immediate guidance for career guidance in elementary schools must be in line with the stages of student development (Gasong, 2018). A person's career development can be seen in the "rainbow career of life" where there are 5 (five) stages of human career development, namely the growth stage, the exploration stage, the establishment stage, the maintenance stage, and the last stage of decline (decline) (Super, 2020). Based on the "rainbow career of life," elementary school students enter the stage of "growth." At this stage, career guidance begins with an emphasis on developing student career awareness.

Stating that career awareness is part of the career maturity that a child needs to achieve and needs to be given at the beginning of the child's early years of knowing the world of school, namely at the elementary school level (Maree, 2018). Some suitable career guidance and counseling materials for elementary school students include understanding that humans are different, developing self-awareness, and understanding the relationship between education and work (Mufidah, 2019). In addition, the provision of information about employment for students in grades 4 to 6 in elementary schools, including the development of self-concepts, developments in the concepts of the world of work, increased 
responsibility for planning time, implementing decision-making, and classification of skills. The required social development, the development of work attitudes and values.

In the Student Development Standards (SKKPD) for elementary school students, it is also stated that at the introduction level, students are expected to analyze a variety of jobs and activities of people in the environment (Rohmah, 2018). To achieve this, schools are expected to be able to optimize education and teaching. So that what is given to students has benefits for the development of student life. Guidance and counseling services are some of the actual forms that help students develop their lives.

Material and concepts are important to pay attention to, but the use of media also has an important role in delivering learning and services in schools (Lawrence \& Tar, 2018; Chacha et al., 2017; Fitriyah, 2017). Learning media itself is a tool that functions to make it easier to convey learning messages, especially for career guidance. Therefore, the development of career guidance media needs to be done continuously by following the needs and products of the times (Masturah et al., 2018). The current problem is how counseling teachers create career guidance media that is attractive, educational, and practical. Of course, it must be following the characteristics and stages of the student's development.

According to the interviews with grade 6 teachers at SD Islamic Global School Malang, career services do not yet have good media for students. Media in schools is only a picture of the type of work. The results of the interview also explained that the kinds of work introduced were different in each class. From there came the desire to create a more exciting media about job introduction in grade 6 .

One of the media used by counselors/teachers in delivering career counseling services for elementary school children is Pop-up Book. The pop-up book media itself is a three-dimensional prop that can be used to attract attention and stimulate children's imagination. Children can increase knowledge to make it easier for children to know the depiction of the shape of an object (Permana \& Sari, 2018). Pop-up Book is a book or a card that can display 3-dimensional or raised shapes (Wulandari, 2016). The pop-up book itself can be designed according to the needs of the service materials to be provided to students and still pay attention to the learning steps. Pop-up books have the advantage of being able to visualize the display/image to be very attractive. Pop-up books can increase students' interest and enthusiasm in participating in learning (Masturah et al., 2018).

Pop-up book media as a medium for learning / providing varied services can make children happy in carrying out learning activities. But in reality, the use of media that uses career counseling service materials in elementary schools is still very minimal and we can say that it is of little concern considering that there is still a very lack of awareness of the importance of career counseling guidance given since school (Nastiti \& Purwanta, 2019). In line with the description above, the researcher is interested in creating thematic-based media to introduce various professions to be used in career information service programs for elementary school students. Pop-up book media is one of the media that researchers choose to provide career introduction material for elementary school students.

Pop-up book media in providing services can be used as counseling teachers and classroom teachers at the elementary school level as a tool for transferring material which in the end is expected to give good results. With the pop-up book media, the service materials delivered by the teacher are easily accepted by students (N. E. Sari \& Suryana, 2019). The existence of appropriate learning media can facilitate the learning process of students, which in the end the learning outcomes achieved are also satisfying (Lawrence \& Tar, 2018).

The development of this professional pop-up book media pays attention to the level of relevance of the media to be used by counselors/teachers in the service delivery process. In addition, by paying attention to the level of accuracy of the material presented to students, the material presented is specifically packaged, concise, and straightforward. The story of the readability of the media in this development is also considered. The content in the material presented is considered appropriate to read and easy to read and understand. The level of feasibility is also an essential aspect in making this media. 
Several research results indicate that Pop-up Book media is very helpful in service delivery performance. This is evidenced in two studies on the development of the Pop-up Career book for primary school student career awareness (Mufidah, 2019) and the development of career introduction Pop-up media for Class III Students of SDN Tambakagung Puri Mojokerto (Praditya, 2016). It is hoped that the Pop-Up Book will make students more enthusiastic and understand so that students can be active in learning activities in class and earn achievements. The learning process requires media that will facilitate both demonstration and practice (Mudlofir, 2021). Therefore students are expected to be creative in making their media and learning tools. These reasons underlie the researchers to develop the Pop-Up Book profession as a career service medium for elementary school students.

\section{B. Methodology}

The design of this research is a development using the Research and Development (R\&D) method by Borg and Gall. There are several stages in this research, namely: planning, product development, product testing, and product trial revision, until it becomes the final product. The instruments used were an assessment scale and a readability questionnaire for trials on elementary students. The research sample was selected using the simple random sampling technique. The research subjects were elementary school students in grade 6 with a total of 35 respondents. A total of 30 respondents to complete the pre-product development assessment, and five respondents to assess the products that have been developed. To evaluate the level, relevance, accuracy, readability, and feasibility of media, researchers involved three expert validators (material experts, media experts, and elementary school education experts). The data obtained are quantitative in the form of assessment results in the assessment format, qualitative data in the form of suggestions or criticism from experts and potential product users in the suggestion sheet, and analyzed by manual counting using a formula to determine the average number of assessments from experts. The procedure used is as follows:

$$
\begin{gathered}
\bar{x}=\frac{\sum x}{n} \\
\text { Information: } \\
\mathrm{n}=\text { the number of each item } \quad \bar{x}=\text { mean } \quad \sum x=\text { total score }
\end{gathered}
$$

\section{Result and Discussion}

This research was conducted in class VI even semester in an elementary school in the city of Malang. The development of this pop-up book media uses the Research and Development (R \& D) development model that the researcher has simplified according to the researcher's needs into three stages: 1) the planning stage, including observation and analysis of the results of the Need Assessment. 2) the product development stage. At this stage, the researcher determines the purpose of the creation, drafts the draft, compiles the contents of the pop-up book, and compiles a prototype for development. 3) the product trial stage; at this stage, the researcher conducted two trials, namely validation with three related experts and the second, testing prospective product users (limited test).

In the first stage, namely the planning stage, the researcher carried out observations and analysis of the needed assessment results. The results of the need assessment analysis show that students' characteristics are students who enjoy learning to use visual media with unique and interesting pictures. More details can be seen in Table 1, below: 
Ricco Rivaldi Hasti, et al.

Pop-Up Book of Profession as a Career Service Media for Elementary School Students

Table 1. Conversion of Assessment Results

\begin{tabular}{|l|l|c|c|}
\hline No. & \multicolumn{1}{|c|}{ Profession } & F & P \\
\hline 1. & PHARMACIST & 2 & 0,98 \\
\hline 2. & ARTIST & 10 & 4,90 \\
\hline 3. & ARCHITECT & 9 & 4,41 \\
\hline 4. & ASTRONOT & 10 & 4,90 \\
\hline 5. & BARTENDER & 6 & 2,94 \\
\hline 6. & DOCTOR & $\mathbf{1 8}$ & $\mathbf{8 , 8 2}$ \\
\hline 7. & TEACHER & $\mathbf{1 9}$ & $\mathbf{9 , 3 1}$ \\
\hline 8. & ENGINEER & 7 & 3,43 \\
\hline 9. & CHEF & 11 & 5,39 \\
\hline 10. & MACHINIST & $\mathbf{1 6}$ & $\mathbf{7 , 8 4}$ \\
\hline 11. & SKILLS & $\mathbf{1 7}$ & $\mathbf{8 , 3 3}$ \\
\hline 12. & PAINTER & 7 & 3,43 \\
\hline 13. & SINGER & 8 & 3,92 \\
\hline 14. & DANCER & 6 & 2,94 \\
\hline 15. & PILOT & $\mathbf{1 4}$ & $\mathbf{6 , 8 6}$ \\
\hline 16. & POLICE & $\mathbf{1 5}$ & $\mathbf{7 , 3 5}$ \\
\hline 17. & PSYCHOLOGIST & 7 & 3,43 \\
\hline 18. & FIREFIGHTERS & $\mathbf{1 4}$ & $\mathbf{6 , 8 6}$ \\
\hline 19. & MASTER OF CEREMONY & 6 & 2,94 \\
\hline 20. & JOURNALIST & 2 & 0,98 \\
\hline & & 204 & 100 \\
\hline & & & \\
\hline
\end{tabular}

Table 1 shows the analysis results obtained by seven preferred and desirable professions (in bold) from the 20 professions that the researcher has mentioned on the need assessment sheet. From the results of the need assessment on teacher representation, it can also be concluded that pop-up book media is considered capable and relevant when applied to learning media/service delivery to students.

The second stage is the product development stage which includes several activities such as product development, drafting, prototyping. At this stage, the researcher makes the purpose of making the pop-up book and compiling the contents/content published in the professional pop-up book. The design creation is also carried out at this stage. Making the prototype itself takes a long time, about one month, to create the characters "Bimbi and Kosi," which are the icons of the media. The meaning of the character "Bimbi" is Guidance, and "Kosi" is Counseling. The purpose of naming this icon with this title is to know better what Guidance and Counseling is. The icons "Bimbi" and "Kosi" can be seen in Figure 1 below:

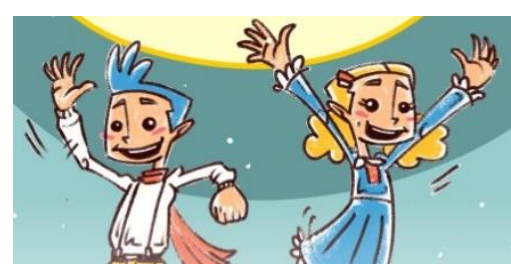

Figure 1. The Icon of Bimbi and Kosi

The third stage is product testing. The professional pop-up book media is prepared according to the career information needs of elementary school students. Product trials were carried out, and the first product trial was expert testing/validation. The validation process involves three validators who have backgrounds under the required fields of knowledge. Two validators to assess the level of relevance, readability, and accuracy of content with guidance and counseling, and one validator from the field of primary school education to assess the feasibility 
Ricco Rivaldi Hasti, et al.

Pop-Up Book of Profession as a Career Service Media for Elementary School Students

level of the media to be applied to elementary school students. The second product trial is a smallscale product trial involving five students.

The fourth stage is validating the material or content in the professional pop-up book involving two validators. More details can be seen in Table 2 below:

Table 2. Expert Test on the Material

\begin{tabular}{|c|c|c|c|}
\hline \multicolumn{2}{|c|}{ Relevance } & \multicolumn{2}{|c|}{ SCORE } \\
\hline No. & Statement & Validator 1 & Validator 2 \\
\hline 1. & The material is relevant to the competencies that students must master & 4 & 5 \\
\hline 2. & The material description meets the demands of the curriculum & 4 & 4 \\
\hline 3. & The number of illustrations that are functional is sufficient & 4 & 5 \\
\hline 4. & Reflection of relevant material with competence & 4 & 4 \\
\hline 5. & The number of reflections is sufficient & 4 & 3 \\
\hline & Total & \multicolumn{2}{|c|}{41} \\
\hline & Average & \multicolumn{2}{|c|}{4,1} \\
\hline & Criteria & \multicolumn{2}{|c|}{ Very Relevant } \\
\hline \multicolumn{2}{|c|}{ Accuracy } & & \\
\hline 6. & The material presented is in accordance with scientific truth & 4 & 4 \\
\hline 7. & The material presented is in accordance with the latest developments & 5 & 3 \\
\hline 8. & $\begin{array}{l}\text { The packaging of the material is in accordance with the scientific } \\
\text { approach concerned }\end{array}$ & 5 & 5 \\
\hline & Total & \multicolumn{2}{|c|}{26} \\
\hline & Average & \multicolumn{2}{|c|}{4,3} \\
\hline & Criteria & \multicolumn{2}{|c|}{ Very Accurate } \\
\hline \multicolumn{2}{|c|}{ Readability and Communicability } & & \\
\hline 9. & The accuracy of using the language and spelling used & 5 & 4 \\
\hline 10. & The accuracy of adjusting the sentence structure & 5 & 4 \\
\hline 11. & The sentence structure is in accordance with the students' understanding & 5 & 4 \\
\hline & Total & \multicolumn{2}{|c|}{27} \\
\hline & Average & \multicolumn{2}{|c|}{4,5} \\
\hline & Criteria & \multicolumn{2}{|c|}{$\begin{array}{l}\text { Very Readable and } \\
\text { Communicative }\end{array}$} \\
\hline
\end{tabular}

Table 3. Expert Test on Madia

\begin{tabular}{|c|l|c|}
\hline No. & \multicolumn{1}{|c|}{ Statement } & SCORE \\
\hline 1. & Suitability of media with learning / service objectives & 5 \\
\hline 2. & The suitability of the media as a learning resource & 5 \\
\hline 3. & The ability of the media in developing student motivation to learn & 5 \\
\hline 4. & The media's ability to attract students' attention & 5 \\
\hline 5. & The ability of the media as a tool to understand and remember information & 5 \\
\hline 6. & The ability of the media to repeat what is learned & 5 \\
\hline 7. & The ability of the media as a student stimulus. & 5 \\
\hline 8. & The ability of the media in delivering services to students & 4 \\
\hline 9. & Ease of media in learning and learning practices & 4 \\
\hline 10. & Media efficiency in terms of time, cost and energy & 4 \\
\hline 11. & The writing presented in the media is clear & 5 \\
\hline 12. & Image quality in media & 5 \\
\hline 13. & Color fidelity in media $\quad$ Total & 5 \\
\hline 14. & The suitability of the illustrations in the media & 5 \\
\hline 15. & Media display suitability Criteria & 72 \\
\hline & & Very feasible to be \\
\hline & developed, and used as an \\
\end{tabular}


Ricco Rivaldi Hasti, et al.

Pop-Up Book of Profession as a Career Service Media for Elementary School Students

Table 3 shows the validation results obtained by an average score of 4.8 (four-point eight). These results indicate the criteria that this pop-up book media is very suitable to be used as media and applied to elementary school students.

The fifth stage is a small-scale product trial involving five students at an elementary school in Malang. At this stage, the researcher uses the questions that the researcher compiles. The questions that the researcher uses have passed the expert test/validation stage along with the weighted values that the researcher uses. More details can be seen in Table 4 below:

Table 4. Expert Test on Products

\begin{tabular}{|c|c|c|c|c|c|c|}
\hline \multirow{2}{*}{ No. } & \multirow{2}{*}{ Questions } & \multicolumn{5}{|c|}{ SCORE } \\
\hline & & Resp1 & Resp2 & Resp3 & Resp4 & Resp5 \\
\hline 1. & Do you know what profession is? & 15 & 15 & 15 & 15 & 15 \\
\hline 2. & How many professions have tutored \& co-explained? & 5 & 5 & 5 & 5 & 5 \\
\hline 3. & How is a teacher's job? & 10 & 10 & 10 & 10 & 10 \\
\hline 4. & $\begin{array}{l}\text { Does being a firefighter have to be brave? What is the reason } \\
\text { ? }\end{array}$ & 25 & 20 & 20 & 15 & 20 \\
\hline 5. & What is the duty of a captain? & 25 & 15 & 22 & 22 & 22 \\
\hline 6. & When you grow up, what profession do you want to be? & 10 & 10 & 10 & 10 & 5 \\
\hline \multirow{2}{*}{\multicolumn{2}{|c|}{ Total }} & 90 & 75 & 82 & 77 & 77 \\
\hline & & \multicolumn{5}{|c|}{401} \\
\hline & Average & \multicolumn{5}{|c|}{80,2} \\
\hline
\end{tabular}

Table 4 shows the average value of 80.2 (eighty points two) from the product trial process. With these results, the pop-up book media reaches the very appropriate assessment criteria for a media career information service for elementary school students. Then all the data that has been obtained is collected and used to revise the product so that it becomes the final product following the product user.

The professional pop-up book as a medium for primary school student career services developed by researchers has fulfilled relevance, accuracy, readability, and feasibility. In making a prototype, the writer does not forget that there are text design principles that must be considered by the design theory developed by (Sudarmika et al., 2018). There are six principles in designing text and images, namely, the first is a positive impression of the learning media designed by the characteristics of students, the second is the readability of the text by using language that is light, easy to understand, and simple. The third aspect that must be considered is the clarity of the illustration. Fourth, late arrangement or placement of components in the media presented. The fifth aspect that must be considered is the level of attractiveness of the image, whose function is to increase students' attractiveness to read it. The last element is to arouse a student's interest in using the media in learning.

The use of media for elementary school children must be media that can make elementary school children interested and have their imagination (Puspitarini \& Hanif, 2019). A pop-up book is a $3 \mathrm{D}$ book that can be used as a service/learning medium for elementary school children, which has unique and different characters in each book, depending on the content you want to displaythe type of pop-up you want to show. The use of pop-up book media in providing counseling services in the field of career guidance in elementary schools is expected to help students reach the career stages according to their age.

Grade 6 elementary school students enter a tentative stage that sometimes occurs in children aged 11-18. At this stage, children tend to consider their career decisions based on pleasure, interest, or interest. The use of this pop-up book is used in providing career services in the form of a professional introduction. The introduction of this profession aims to increase the career awareness of elementary students. The initial stage of career development based on Super 
career theory starts from the career awareness stage (Pulliam \& Bartek, 2018). Furthermore, Savickas (2020) also states that the stages of career development start from elementary school, focusing on self and awareness. The junior high school level focuses on career exploration and planning. At the high school level focuses on decision making, and intermediate and at the university level focuses on career planning and placement.

This pop-up book media has various benefits, namely: 1) teaching children to appreciate books more and treat them better, 2) bringing children closer to their parents because the pop-up book has a smooth section to provide an opportunity for parents to sit together with them. Their children and enjoy stories (bringing the relationship between parents and children closer), 3) developing children's creativity, 4) stimulating children's imagination, 5) increasing knowledge to provide a depiction of the shape of an object (object recognition). The most important thing to note is that this pop-up book media can be used as a medium to instill children's love for reading (N. E. Sari \& Suryana, 2019).

Several research results have shown that this pop-up book media is effective in explaining puberty material (DV Sari \& Kusmariyatni, 2020), increases focus and object recognition abilities for autistic children (Nazaruddin \& Efendi, 2018), provides an initial introduction to the profession (Widhiastuti, 2020), improves children's language skills (Pratiwi et al., 2020) and can improve students' Social Care Character (Nisa, 2020).

\section{Conclusion}

The professional pop-up book as a medium for primary school student career services developed by researchers has fulfilled relevance, accuracy, readability, and feasibility. This media is declared valid and can be used as an alternative media to provide career information services for elementary school students. Expert testing and testing of prospective product users obtained 80.2 results with very feasible criteria to be applied and used as an alternative media.

Suggestions given regarding the development of pop-up book media are as follows: 1) Pop-up book media can not only be used for students in group learning but this media can also be used in individual learning, 2) This media also does not only work. Used in group guidance services, but can also be used and applied when classical services, 3) it is hoped that teachers/researchers can develop similar learning media with different service content.

\section{E. References}

Chacha, F., Mwanda, S., \& Midigo, R. (2017). Use of Instructional Media in Elementary Schools in Kenya: Understanding Teacher Attitude and Perceived Pedagogical Value of Picture Books. International Journal of Elementary Education, 6(6), 53.

Eliason, G. T., Lepore, M., Samide, J. L., \& Patrick, J. (2019). Career development across the lifespan: Counseling for community, schools, higher education, and beyond. IAP.

Fitriyah, F. K. (2017). Reducing Aggressive Behavior Using Solution-Focused Brief Counseling (SFBC). JBKI (Jurnal Bimbingan Konseling Indonesia), 2(2), 34-39. https://doi.org/http://dx.doi.org/10.26737/jbki.v2i2.254

Gasong, D. (2018). Belajar dan Pembelajaran. Deepublish.

Istiqomah, H., \& Suyadi, S. (2019). Perkembangan Fisik Motorik Anak Usia Sekolah Dasar dalam Proses Pembelajaran (Studi Kasus di SD Muhammadiyah Karangbendo Yogyakarta). El Midad, 11(2), 155-168.

Kurniasih, V. W., Fitriyah, F. K., Hidayat, M. T., \& Sunanto. (2020). Hubungan Pemahaman

Diri Terhadap Rasa Tangung Jawab: Sebuah Survey pada Anak Usia Dini di Kota

Surabaya. Child Education Journal, 2(2), 98-105. https://doi.org/10.33086/cej.v2i2.1672

Lawrence, J. E., \& Tar, U. A. (2018). Factors that influence teachers' adoption and integration 
Ricco Rivaldi Hasti, et al.

Pop-Up Book of Profession as a Career Service Media for Elementary School Students

of ICT in teaching/learning process. Educational Media International, 55(1), 79-105.

Maree, J. G. (2018). Promoting career development and life design in the early years of a person's life. Early Child Development and Care, 188(4), 425-436.

Masturah, E. D., Mahadewi, L. P. P., \& Simamora, A. H. (2018). Pengembangan Media Pembelajaran Pop-Up Book Pada Mata Pelajaran IPA Kelas III Sekolah Dasar. Jurnal EDUTECH Undiksha, 9(2).

Mudlofir, H. A. (2021). Desain Pembelajaran Inovatif: Dari Teori ke Praktik. PT. RajaGrafindo Persada.

Mufidah, E. F. (2019). Pengembangan Buku Pop-Up Karier untuk Kesadaran Karier Siswa Sekolah Dasar. INSIGHT: Jurnal Bimbingan Konseling, 8(2), 136-143.

Nastiti, R. B., \& Purwanta, E. (2019). Introducing career to kindergarten students. Psychology, Evaluation, and Technology in Educational Research, 2(1), 10-21.

Nazaruddin, M. A., \& Efendi, M. (2018). The book of pop up augmented reality to increase focus and object recognition capabilities for children with autism. Journal of ICSAR, 2(1), 914.

Nisa, L. (2020). The Effect of Story Telling Activity Using Pop-Up Book on the Social Caring Character. International Conference on Early Childhood Education and Parenting 2009 (ECEP 2019), 164-169.

Permana, E. P., \& Sari, Y. E. P. (2018). Development of Pop Up Book Media Material Distinguishing Characteristics of Healthy and Unfit Environments Class III Students Elementary School. International Journal of Elementary Education, 2(1).

Praditya, S. Y. (2016). Pengembangan Media Pop Up Pengenalan Karir Untuk Siswa Kelas Iii SDN Tambakagung Puri Mojokerto. Jurnal BK Unesa, 6(1).

Pratiwi, K. B., Sugito, M. S., \& Subandowo, M. (2020). The Development Pop-Up Books To Improve Children's Language Skills. Jurnal Kajian Teknologi Pendidikan, 3(4), 408414.

Pulliam, N., \& Bartek, S. (2018). College and career readiness in elementary schools. International Electronic Journal of Elementary Education, 10(3), 355-360.

Puspitarini, Y. D., \& Hanif, M. (2019). Using Learning Media to Increase Learning Motivation in Elementary School. Anatolian Journal of Education, 4(2), 53-60.

Rohmah, U. (2018). Bimbingan Karir untuk Peserta Didik di Sekolah Dasar. Cendekia: Jurnal Kependidikan Dan Kemasyarakatan, 16(2), 262-282.

Sari, D. V., \& Kusmariyatni, N. (2020). The Validity of the Pop-Up Book Media on Puberty Topics for Sixth Grade Elementary School. International Journal of Elementary Education, 4(2), 179-186.

Sari, N. E., \& Suryana, D. (2019). Thematic Pop-Up Book as a Learning Media for Early Childhood Language Development. Jurnal Pendidikan Usia Dini, 13(1), 43-57.

Savickas, M. L. (2020). Career construction theory and counseling model. Career Development and Counseling: Putting Theory and Research to Work, 165.

Sudarmika, K. B., Parmiti, D. P., \& Simamora, A. H. (2018). Pengembangan Media Ular Tangga Inovatif untuk Meningkatkan Minat Belajar Siswa Kelas IV Sekolah Dasar. Jurnal EDUTECH Undiksha, 9(2).

Super, D. E. (2020). Life-Span, Life-Space Career Theory and Counseling. Career Development and Counseling: Putting Theory and Research to Work, 95.

Susanto, A. (2016). Teori belajar dan pembelajaran di sekolah dasar. Kencana.

Widhiastuti, R. (2020). Pop Up Book Design as an Introduction Media About Profession for Early Children. Arty: Jurnal Seni Rupa, 9(1), 70-80.

Wulandari, T. (2016). Pengembangan Media Cetak Kirigami Pop Up Materi Perkembangan Kebudayaan Pengaruh Islam di Indonesia Pada Mata Pelajaran IPS SMP Kelas VII. SOCIAL STUDIES, 5(9).

Yasmin, S., Rumi, M. A., \& Robert, S. (2020). Impact of Pre-primary Education on Children in Bangladesh: A Study on Government Primary Schools in Sylhet City. American Journal of Educational Research, 8(5), 251-258. 